Jusmal lemiah
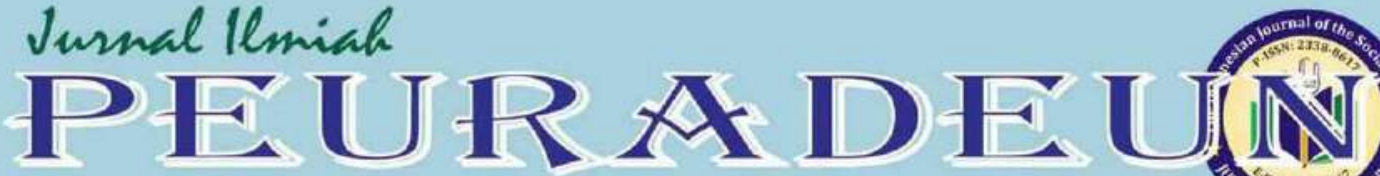

Vol. 6, No. 1, January 2018

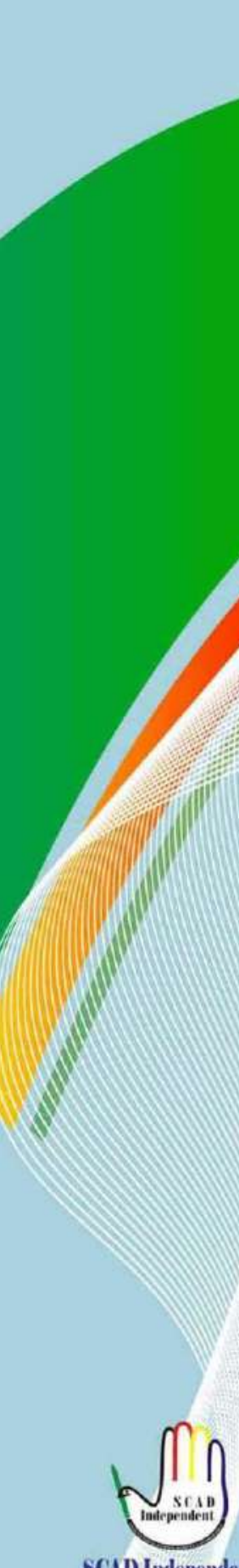

SCAI) Independent Accreditatioa by HO since 2014 $\bigodot$ Copernicus Publications

\section{III}

The Indonesian Journal of the Social Sciences www.journal.scadindependent.org Dot Prefix Number: 10.26811

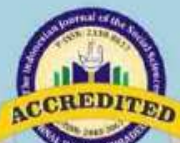

ACCREDITED - B" by the Ministry of Risteklikti from Oetaber 30, 2017 until Oetober 30, 2022

\section{Clarivate Analytics}

Emerging Sources Citation Index Web of Science ${ }^{\mathrm{TM}}$

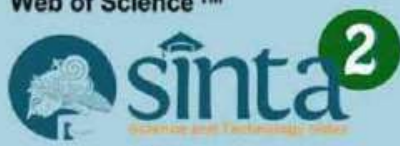
INDEX $\circledast$ COPERNICUS 


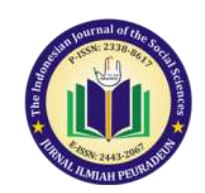

\title{
ANDING-ANDINGEN IN THE PERSPECTIVE OF SYSTEMIC FUNCTIONAL LINGUISTICS
}

\author{
Immanuel Prasetya Gintings ${ }^{1}$; Tengku Silvana Sinar ${ }^{2}$; Amrin Saragih ${ }^{3}$ \\ 1,3Universitas Negeri Medan, North Sumatra, Indonesia \\ ${ }^{2}$ Universitas Sumatera Utara, North Sumatra, Indonesia \\ Contibutor Email: manuprojectpro@gmail.com
}

Received: Jun 22, 2017

Accepted: Aug 18, 2017

Published: Jan 28, 2018

Article Url: http://journal.scadindependent.org/index.php/jipeuradeun/article/view/176

\begin{abstract}
Systemic Functional Linguistics (SFL) concerns three metafunction meanings: clause as message, clause as exchange, and clause as representation. This article tries to analyze anding-andingen, one of oral tradition in Karo culture. The points of this paper are only two kinds of metafunctions could be applied to anding-andingen: clause as message and clause as representation. The clause of exchange could not be applied to anding-andingen since anding-andingen is an Adjunct form so it does not have the potential to be Subject; Therefore, it cannot be upgraded to an interpersonal status of capital responsibility. Anding-andingen form cannot be categorized as a clause because at the semantic level, although its form resembles a clause, but is used to describe a person's nature or condition. In using anding-andingen, if the clause is preceded by a nominal group of Subject and followed by anding-andingen as a prepositional phrase or adverbial group, the textual function will be Rheme, but if the clause begins with anding-andingen, it will be Marked Theme.
\end{abstract}

Keywords: Systemic Functional Linguistics, Anding-Andingen, Oral Tradition 


\section{A. Introduction}

Each tribe has its own characteristics that distinguish it from other tribes. This characteristic can be derived from the rules of life owned by each of these tribes, thus regulating the manner of their behavior in the life of society. Karo community is one of the people in North Sumatera that inhabits the mountain area of Karo Regency and some areas of Deli Serdang, Langkat, and partly in Dairi Regency.

Anding-andingen is one form of oral tradition that has a role and position that covers various aspects of life in Karo culture. According to Bangun (1986: 66-68), in addition to anding-andingen several other oral tradition of Karo are: Tabas (spell used by shaman or "guru si baso"), ndung-ndungen (rhyme or four-line poem, with the first two lines of sampiran, and the last two lines are contents), turi-turin (an oral story containing history inserted advice and cultural values in it), bilang-bilang (laments being sung), ermangmang (a tribal speech without a text delivered by shaman or "guru si baso" which capable of arousing the listener's feelings) And cakep lumat (subtle language used by certain people who are expert in conveying messages through sayings, proverbs, imagery, puzzles, rhymes, and poems).

In Karo culture, Karo people recognize the order of life that limits their behavior in everyday life. This is the cultural values that Karo traditional society retains in the form of ethical values that they uphold. In the classic story or "turi-turi si adi" of Karo, there is an expression that says, "jelma si mehamat emkap jelma si banci janah ngasup meneken ras nasapken sumbang si siwah $i$ bas kinigeluhenna nari" which means, "a gentleman is the one who is want and able to eliminate and necessitate nine bans of life". This nine restrictions or taboos are: sumbang perkundul (prohibition of how to sit), sumbang pengerana (prohibition of way of speaking), sumbang pengenen (prohibition of viewing), sumbang perpan (prohibition of how to eat), sumbang perdalan (prohibition of walking), sumbang perdahin (prohibition of how to work or behave), sumbang 
perukuren (prohibition of way of thinking), sumbang peridi (prohibition of bathing), and sumbang perpedem (prohibition of sleep).

Especially about the prohibition of speech, Karo people are very concerned about how to speak. Speech, indecency, rude, discordant, and forbidden is always avoided in everyday life. Speeches that make others offended are greatly avoided, but conversely words that can make others happy are highly respected by the Karo community. In the famous Karo society a reply, "Ula kataken si tuhuna, kataken lah si tengtengna" which means, "Do not tell the truth, but say that fits in the heart (of the listener)". This became the phenomenon of language that influenced the Karo cultural ideology, which in the end they used figurative meaning in conveying something to others, as well as the result of the enactment of rebu or taboo in social relations. As a hallmark of this is the use of andingandingen in communicating with other in Karo society. They are more likely to use other subtle variations of language, and in this case they use anding-andingen that is easily understood by the other person.

The previous literature which became one of the sources of data in this research is the book "1000 Perumpamaan Karo" by Singarimbun (1960). Although Singarimbun uses the word "perumpamaan" (parable) as the title of his book, in the explanation of the use of the parable clauses, he used the terms "andingen" and "iandingken" which refers to the use of the term "perumpamaan" in his book. In line but different from the form written by Sembiring (1994) who created a new anding-andingen which he authored as "illustrations stories" used to convey Christian religious messages that take metaphors in the form of things that are commonly found in the lives of Karo people. Anding-andingen collected by Singarimbun are familiar anding-andingen used by the Karo community around 1954 - 1955. Likewise, 300 anding-andingen are collected and written by Tarigan obtained through a written source in Leiden and oral sources of Karo society. According to Singarimbun, Karo's anding-andingen has some additional information and some are not; it can be called first or behind it, as does the Malay parable that uses the word "like". 
The form of text that is a metaphor in anding-andingen happens because of the context that affects the delivery of the true meaning. This is a metaphorical model of an expression, in which the relationship between lexicogrammar and semantics can be observed to be clearly observed in anding-andingen. A text is thus a unit of meaning - more accurately, a unit in the flow of meaning that is always taking place at the instance pole of the cline of instantiation. A text consist of clauses (or 'sentences'); but this is a misleading simplification of a more indirect - but much more flexible and powerful - relationship. A text does not 'consist of' clauses (clause complexes) - there is no part-whole or 'constituency' relationship between a text and a clause (complex) and there is no single rank scale with text and clause as ranks. Rather a text is realized by clauses (clause complexes), the two being located on different strata - semantics (the stratum of meaning) and lexicogrammar (the stratum of wording) respectively. The notion that language is stratified into an ordered series of levels or strata that are related by realization was introduced by Halliday (2014:7-10) and this type of organization of language was represented diagrammatically in Figure 1-1 below:

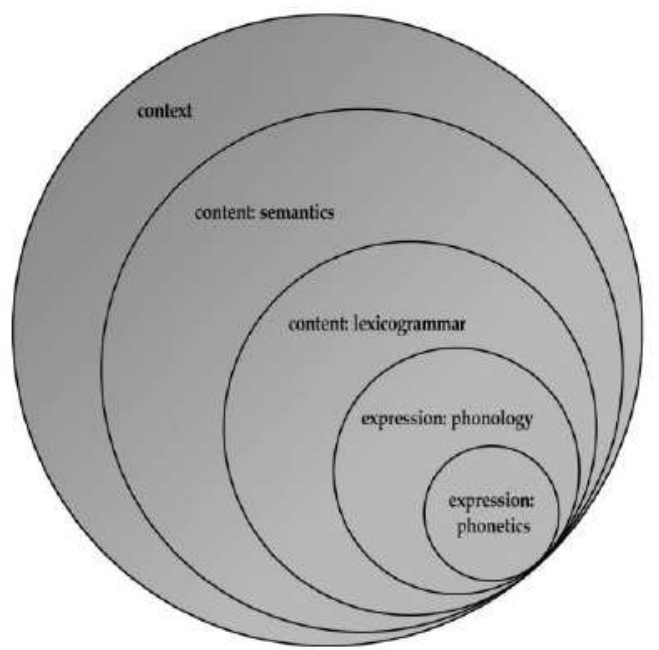

Fig. 1-1 Stratification (Halliday, 2014:26) 
Previous Systemic Functional Linguistic Research on the form of anding-andingen has never been done before. Some studies of figurative languages, proverbs, poetry and other oral traditions have been extensively researched, but the anding-andingen form collected by Singarimbun is different because it is not a clause in the text but a collection of phrases or word groups so that the analysis of how this anding-andingen form Become very interesting to study. Due to the words choices that are interesting and different from the ordinance of conveying the message in the usual way, through this research the questions to be answered based on Systemic Functional Linguistic are: "what are the things that Karo society passes through anding-andingen?", "how they deliver it through anding-andingen?", and "why did they convey it through anding-andingen?"

\section{B. Method}

This research employs Systemic Functional Linguistics as the main theoretical framework to discussing the usefulness of this linguistics theory in qualitative data analysis.

\section{Research Finding}

To compare the strata of meaning represented by the lexicogrammar strata from anding-andingen can be done more easily and valid as it is obtained through data collected by Singarimbun directly from the Karo community directly. As a comparison, the use of words or terms in anding-andingen can also be traced to the meaning of the Karo dictionary by Prinst.

\section{Experiential function}

The first stage in analyzing anding-andingen's form is by looking at the embodiment of semantic domains of anding-adingen. Seen from its form, the dominant anding-andingen is not in the form of a clause. There 
are several forms of anding-andingen that resemble clauses, for example on the following anding-andingen:

Ganjangen bereng-bereng asang kuliki. (Singarimbun, 1960: 25)

("Higher - beetle than eagle")

Ombakken lau sada cangkir. (Singarimbun, 1960: 101)

("Drifted by one cup of water")

This anding-andingen form cannot be categorized as a clause because at the semantic level, although its form resembles a clause, but is used to describe a person's nature or condition. The use of the word "like" is not written on this anding-andingen type, but it seems to be an ellipsis. The "like" marker is a preposition form so that the most appropriate form for anding-andingen is the prepositional phrase and adverbial groups. From this form, it was found that the form most suited to the use of prepositional phrases and adverbial groups in the experiential function is Circumstance: Manner.

Halliday (2014: 318) defined that the circumstantial element of Manner construes the way in which the process is actualized. Manner comprises four subcategories: Means, Quality, Comparison, and Degree. These cover a considerable range; Means is close to the participant role of Agent and Comparison is like a participant in a clause with the same kind of process, whereas Quality and Degree are like features of the Process itself. These differences in status are reflected in realizational tendencies: Means and Comparison tend to be realized by prepositional phrases, whereas Quality and Comparison tend to be realized by adverbial groups.

Comparison is typically expressed by a prepositional phrase with "like" or "unlike", or an adverbial group of similarity or difference. It is predominantly found in the form of anding-andingen, in which the dominant "bagi" ("like") word is found, for example:

Bagi belkih ketang, meliar. (Singarimbun, 1960: 20)

("Like a rattan deer")

Bagi si negu kambing. (Singarimbun, 1960: 69)

("Like herding goats") 


\section{Interpersonal function}

Because they function as 'circumstance' in the transitivity structure of the clause, anding-andingen was referred as circumstantial Adjuncts. These are experiential in metafunction. Halliday (2014: 154) defined that an Adjunct is an element that has not got the potential of being Subject; that is, it cannot be elevated to the interpersonal status of modal responsibility. This means that arguments cannot be constructed around those elements that serve as Adjuncts; in experiential terms, they cannot be constructed around circumstances, but they can be constructed around participants, either actually, as Subject, or potentially, as Complement. They are three degrees of interpersonal ranking or elevation in the clause, as shown in Figure 1-2: Subject - Complement - Adjunct.

$\begin{array}{llll}\text { modal responsibility } & \begin{array}{l}\text { actual } \\ \text { potential } \\ \text { modal responsibility }\end{array} & \text { none } & \begin{array}{l}\text { Subject } \\ \text { Complement } \\ \text { Adjunct }\end{array}\end{array}$

Fig. 1-2 Degree of Interpersonal (Halliday, 2014:26)

An Adjunct is typically realized by an adverbial group or a prepositional phrase (i.e. preposition + nominal group rather than by a nominal group). A prepositional phrase, however, has its own internal structure, containing a nominal group serving as Complement within it. Anding-andingen can be analyzed through the nominal group that follows it and also makes anding-andingen unrelated to a particular type of speech function. Anding-andingen can be used for declarative, imperative, and even interrogative sentences.

\section{Textual Function}

In using anding-andingen, if the clause is preceded by a nominal group of Subject and followed by anding-andingen as a prepositional phrase or 
adverbial group, the textual function will be Rheme, but if the clause begins with anding-andingen, it will be Marked Theme.

\section{Discussion}

To answer the first problem in this study, it was found that the anding-andingen of its SFL form analysis is a prepositional phrase or adverbial group functioning as Circumstance: Manner: Comparison. Anding-andingen is an Adjunct form so it does not have the potential to be Subject; Therefore, cannot be upgraded to an interpersonal status of capital responsibility. In experiential terms, they cannot be constructed around the circumstances, but they can be constructed around the participants, as well as, as Subject, or potentially, as complement. To make anding-andingen into Unmarked Theme form, it takes a nominal group of Subject. Furthermore, to answer what the Karo people say through andingandingen, it can be traced through the nominal group that is the agent of the process involving anding-andingen as its circumstance. The keyword that can be used to search is located in the prepositional "like" that characterizes anding-andingen. This word is used to describe something by comparison. The process that is closest to this form is relational processes - the processes to relate one fragment of experience to another in some kind of taxonomic relationship: this is the same as that; this is a kind of the other.

Relational processes are those of identifying and classifying. In any 'identifying' clause, the two halves refer to the same thing; but the clause is not a tautology, so there must be some difference between them. This difference can be characterized as a strata one of 'expression' and 'content'; or, in terms of their generalized labels in the grammar, of Token and Value - and both can be used to identify the other. Token is 'decoded' or else the Value is 'encoded'. If the Token is construed as Identified and the Value as Identifier, the clause is a decoding one; if the Value is construed as Identified and the Token as Identifier, the clause is an encoding one. In other words, the identity of the Token by reference to the Value or it 
encodes the Value by reference to the Token. The Value of anding-andingen is the nominal group that is explained by Token which is also a nominal group as in example:

Bagi bunga ndapdap, Megara la erbau. (Singarimbun, 1960: 39)

("Like saga flowers, red but not fragrant").

Likened to someone who is beautiful but apparently unkind.

Bagi kerbo sada ioga. (Singarimbun, 1960: 83)

("Like a buffalo in the same plowing wood.")

Likened to persons with the same fate.

In anding-andingen Karo also found some form of verbal group that become Token as in example:

Ngkimbangi amak babo lubang (Singarimbun, 1960: 8)

("Rolling a mat over the hole").

Likened to someone who looks good, but actually has a bad plan.

Mindo jukut man kancil (Singarimbun, 1960: 70)

("Ask meat to a mouse deer").

Likened to asking the poor.

From the data collected in Singarimbun's book "1000 Perumpaman Karo", there are found some nominal and verbal groups that are Value in anding-andingen, which are: (1) People of certain behavior; (2) the behavior of a person; (3) The person doing a particular job; (4) The work someone is working on; (5) The situation one is facing at the time; (6) Advices; (7) The life principles of Karo society; (8) Physiology/character of one's body; (9) Something (nominal) produced by a person. The most dominant Value found in anding-andingen is a person with certain behavior and with a variety of Token forms such as animals, plants, and some other nominal groups that exist in the daily life of Karo people which is considered to have the same characteristics to describe the person's behavior.

To answer the second question, we review the anding-andingen form in the findings section. Anding-andingen is a form of prepositional phrases and adverbial groups. The form most suited to the use of prepositional phrases and adverbial groups in the experiential function is Circumstance: Manner. Adjunct is an element that has not got the 
potential of being Subject; that is, it cannot be elevated to the interpersonal status of modal responsibility.

"Why did Karo society convey something through anding-andingen?" This last question can be answered through an understanding of the andingandingen function from the observation of its form. Based on the Circumstance function: Manner, it is defined that the circumstantial element of Manner construes the way in which the process is actualized. Comparison is like a participant in a clause with the same kind of process. So from this explanation it can be gathered that the main reason for the use of andingandingen for Karo society is to convey what is comparable to the nominal group in the sentence they use. In this case, based on the findings of the two previous problems, dominant anding-andingen tends to be used to discuss a person with a certain attitude by comparing it with other nominal groups that have the same type of process. This may be a habit of speaking in Karo society because of the rules that applied among them.

\section{E. Conclusion}

Summing up the discussion, it is evident that the functional structural based analysis of the anding-andingen is very useful in order to understand the forms, realizations, and reasons for its use in the life of Karo society. Based on the three, there are only the two kinds of metafunctions could be applied to anding-andingen: clause as message and clause as representation.

The clause of exchange could not be applied to anding-andingen since anding-andingen is an Adjunct form so it does not have the potential to be Subject; Therefore, cannot be upgraded to an interpersonal status of capital responsibility.

Anding-andingen form cannot be categorized as a clause because at the semantic level, although its form resembles a clause, but is used to describe a person's nature or condition. The use of the word "like" is not written on this anding-andingen type, but it seems to be an ellipsis. 
Immanuel Prasetya Gintings et al.

In using anding-andingen, if the clause is preceded by a nominal group of Subject and followed by anding-andingen as a prepositional phrase or adverbial group, the textual function will be Rheme, but if the clause begins with anding-andingen, it will be Marked Theme.

\section{Bibliography}

Bangun, T. (1986). Manusia Batak Karo. Jakarta: Inti Idayu. p 66-68.

Bangun, T. (1990). Penelitian dan Pencatatan Adat Istiadat Karo. Jakarta: Yayasan Marga Silima.

Duranti, A. (1997). Linguistic Anthropology. Cambridge: Cambridge.

Evans, A.S. (2006), "Promoting Happiness through Oral Traditions," Journal of Bhutan Studies, 15:115-132, p.117.

Gintings, E. P. (1994). Adat Istiadat Karo: Kinata Berita Si Meriah I Bas Masyarakat Karo. Kabanjahe: Abdi Karya.

Gintings, E. P., (1999). Religi Karo. Kabanjahe: Abdi Karya.

Halliday, M.A.K and Christian Matthiessen. (2014) Halliday's Introduction to Functional Grammar. New York: Routledge.

Halliday, M.A.K. \& Christian M.I.M. Matthiesen (2014). Functional Grammar. 4th Edition. New York: Routledge

Halliday, M.A.K. \& Ruqaiya Hasan. (1985). Language, context, and text: aspects of language in a social-semiotic perspective. Oxford: Oxford University Press.

Halliday, M.A.K. (1978). Language as Social Semiotics: The Social Interpretation of Language and Meaning. London: Edward Arnold.

Lakoff, G. \& Johnson, M. (1980). Metaphors We Live By. Chicago, IL: University of Chicago Press

Martin, J.R. (1992). English Text: System and Structure. Philadelphia: John Benjamins Publishing.

Martin, J.R., Christian M.I.M. Matthiesen, Claire Painter. (1997). Working with Functional Grammar. London: Arnold.

Meuraxa, D. (1973). Sejarah Kebudayaan Suku-Suku di Sumatera Utara. Medan, Penerbit Sasterawan. 
Muchsin, M. A. (2015). Art and Entertainment in Islam. Jurnal Ilmiah Peuradeun, 3(1), 133-146.

Putro, B. (1981). Karo dari Jaman ke Jaman. Medan: Yayasan Masa.

Saragih, A. (2002). Bahasa dalam Konteks Sosial. Medan: PPs Unimed.

Sembiring, R. (1994). Anding-andingen (Ilustrasi) Karo. Medan: Ulih Saber.

Singarimbun, M. (1960). 1000 Perumpaman Karo. Medan: Ulih Saber.

Singarimbun, M. (1975). Kinship, Descent, and Alliance Among the Karo Batak. California: University of California Press.

Suzanne, R., \& Nathalie, L. (2016). Multiculturalism as an Alternative A Cultural Orientation to Education in the Aspect of Culture as the Axiological Focus. Jurnal Ilmiah Peuradeun, 4(3), 383-394.

Syahril, S. (2014). Arena Produksi Kultural dan Kekerasan Simbolik. Jurnal Ilmiah Peuradeun, 2(1), 75-92. 